BBA 66352

\title{
PLASMA ALKALINE PHOSPHATASE ISOZYMES: ISOLATION AND CHARACTERIZATION OF ISOZYMES
}

\author{
DAVID AMINOFF, MIKELIS AUSTRINS AND S. P. ZOLFAGHARI
}

Departments of Internal Medicine (Simpson Memorial Institute) and Biological Chemistry, The University of Michigan, Ann Arbor, Mich. 48104 (U.S.A.)

(Received February I2th, I97I)

\section{SUMMARY}

I. The two isozymes of alkaline phosphatase (orthophosphoric monoester phosphohydrolase, EC 3.I.3.I) detectable in human blood group O plasma have been separated from one another and isolated in a high state of purity. With $p$-nitrophenyl phosphate as substrate, the catalytic properties of the two isozymes appear to be the same with respect to $\mathrm{pH}$ optimum, I0.5; $K_{m}, 0.35^{-0.4} \mathrm{mM}$, and activity in the presence of EDTA, $\mathrm{Mg}^{2+}$ and $\mathrm{Zn}^{2+}$. The isozymes differ in their electrophoretic mobilities and in their reactivity in the presence of activators and inhibitors. L-Phenylalanine specifically inhibits the minor isozyme.

2. Comparison of the isozymes isolated from plasmas of individuals of different phenotype indicates that the major isozyme is the same in $A, B$ and $O$. The minor isozymes of $\mathrm{B}$ and $\mathrm{O}$ appear to be identical, but they both differ from the minor isozyme detectable in A individuals. Although separable electrophoretically on acrylamide disc electrophoresis and on DEAE-cellulose columns, the minor isozyme from group A individuals appears to have the same catalytic properties as the major component from group A plasma.

\section{INTRODUCTION}

The multiplicity of alkaline phosphatases (orthophosphoric monoesterphosphohydrolase, EC 3.I.3.I) in plasma is readily demonstrated by electrophoretic procedures $^{1-3}$. Attempts have been made to identify the organ of origin of the various isozymes of alkaline phosphatase $\mathrm{e}^{4-6}$. The isozymic pattern in plasma of normal individuals consists of two bands; one, electrophoretically faster migrating, believed to be of bone or hepatic origin, and the other (slower) of intestinal origin. ARFors et $a l .^{7}$ noted a very conspicuous association between the number of phosphatase bands observed and the ABO blood group of the individual. A subsequent publication $^{8}$ suggested further association with the Lewis blood group system. Similar correlations of the blood group with the number of alkaline phosphatase bands detectable in the zymograms were made in cattle ${ }^{\mathbf{9}}$ and sheep $\mathrm{p}^{\mathbf{1 0}}$. In each case there is 
a strong correlation between the absence of one of the phosphatase bands (of "intestinal" origin) and the blood group A character in cattle, sheep and man. This correlation is of interest as it represents the first well-documented case of a physiological parameter associated with a specific blood group of the individual.

A number of hypotheses have been put forward to explain the observed correlation $^{11-13}$. However, as the problem was investigated further, the influence of other genetic as well as temporal factors ${ }^{14}$ became apparent. Indeed, more recent studies have indicated that the detection of the slower "intestinal" isozyme is markedly affected by the diet just prior to sampling of the plasma ${ }^{15}$. And it can be anticipated that the picture will become even more ambiguous so long as the present procedures are used, for it is well known that alkaline phosphatase activity is greatly influenced by a number of substances that are normal constituents of plasma ${ }^{16-19}$.

In order, therefore, to obtain a clearer understanding of the nature and function of the isozymes of alkaline phosphatase, and the role that they might play in the story of the blood groups, it will be necessary to isolate them in pure form. Alkaline phosphatase has been isolated from Escherichia coli ${ }^{20-21}$ as well as in a high state of purity from a number of organs ${ }^{22-26}$, and from sheep serum ${ }^{27}$, but, surprisingly, never as yet from human plasma.

The purpose of this communication is to describe the isolation and purification of the plasma alkaline phosphatases by a number of simple steps, and to further separate the two isozymes and compare their properties, first with one another, and secondly with the two isozymes isolated from plasmas of individuals of different phenotype $\mathrm{A}, \mathrm{B}$ and $\mathrm{O}$.

\section{EXPERIMENTAL PROCEDURE}

\section{Materials}

The crystalline disodium salt of $p$-nitrophenyl phosphate was obtained from Mann Research Laboratories. $p$-Nitrophenol, the product of enzymatic reaction, was obtained from Fisher Scientific Co. This had a molecular extinction coefficient of I.75 ${ }^{1} \mathrm{O}^{4}$ under the conditions of the assay for alkaline phosphatase activity.

The following commercially available materials were used: reagents for polyacrylamide disc electrophoresis (Eastman); starch for the starch gel electrophoresis (Connaught Medical Research Laboratories); DEAE-cellulose (DE52) (Reeve Angel Company, New York, N.Y.); Sephadex G-200 (Pharmacia); collodion bags for dialysis (Schleicher and Schuell Company). It was necessary to wash the bags prior to use, first with 0.0 I $\mathrm{M} \mathrm{NaOH}$, then with o.or $\mathrm{M} \mathrm{HCl}$, followed by distilled water and the $0.05 \mathrm{M}$ Tris-HCl buffer ( $\mathrm{pH} 7.7$ ). Buffalo black, used for the staining of proteins in gel electrophoresis, was obtained from Allied Chemicals. The sodium salts of $\boldsymbol{\alpha}-$ or $\beta$-naphthyl acid phosphate, used as the substrates for the detection of alkaline phosphatase on gel electrophoresis, were obtained from Sigma. The Blue RR salt necessary to develop the colors with the naphthol released was obtained from Allied Chemicals.

The following compounds were tested for their ability to enhance or inhibit the alkaline phosphatase activities of the isozymes: citric acid, $\mathrm{CoCl}_{2} \cdot 6 \mathrm{H}_{2} \mathrm{O}$, sodium tetraborate, $\mathrm{ZnCl}_{2}$ and zinc acetate (Allied Chemicals); $\mathrm{KF}, \mathrm{K}_{3} \mathrm{PO}_{4} \cdot n \mathrm{H}_{2} \mathrm{O}, \mathrm{K}_{2} \mathrm{SO}_{4}$, $\mathrm{MgCl}_{2} \cdot 6 \mathrm{H}_{2} \mathrm{O}, \mathrm{Na}_{2} \mathrm{HAsO}_{4} \cdot 7 \mathrm{H}_{2} \mathrm{O}$ (J. T. Baker Chemical Co.); D-tyrosine (Calbiochem); 
sodium taurocholate (Difco); DL-alanine, EDTA, L-tyrosine (Eastman); $\mathrm{Na}_{2} \mathrm{SO}_{4}$ (Mallinckrodt); deoxycholic acid, D-phenylalanine, L-phenylalanine, oubain (Sigma), bacitracin (Upjohn Co.).

Human plasma used for the isolation of the alkaline phosphatase was of two sources: (a) outdated plasma from individuals of known $\mathrm{ABO}$ phenotypes which had been stored 2I days at room temperature and (b) fresh blood after its clinical use for open heart surgery. This was spun free of erythrocytes, and owing to some mechanical trauma of this blood during clinical use, the resulting plasma invariably had some hemoglobin as a contaminant.

\section{Methods}

Total protein in eluates from the chromatographic columns was determined by the absorbance at $280 \mathrm{~nm}^{28}$, while the protein content of the various fractions was determined by the microbiuret procedure ${ }^{29}$ using bovine serum albumin as standard.

Starch gel electrophoresis was performed by the horizontal method of SMгтнiEs ${ }^{30}$ in borate buffer ( $\mathrm{pH}$ 9.0). The starch and buffer concentration used varied with each particular lot of starch but in general was approximately $\mathrm{I} 2 \mathrm{~g}$ starch per Ioo $\mathrm{ml}$ of $0.02 \mathrm{M} \mathrm{H}_{3} \mathrm{BO}_{3}$ and $8 \mathrm{mM} \mathrm{NaOH}$. The electrophoretic separation time was $17 \mathrm{~h}$ at $6 \mathrm{~V} / \mathrm{cm}$ at $4^{\circ}$. The isozymes of alkaline phosphatase were visualized by staining $5 \mathrm{~h}$ at $37^{\circ}$, with sodium $\alpha$-naphthyl acid phosphate and Blue RR salt in $0.05 \mathrm{M}$ Tris-HCl buffer $(\mathrm{pH} 8.8)^{31}$. Destaining was achieved in $\mathrm{I} 8 \mathrm{~h}$ soaking in methanol-water-acetic acid (5:5:I, by vol.).

Disc electrophoresis in polyacrylamide was performed by a modification of the procedure of DAvis ${ }^{32}$ with the use of $10 \%$ cyanogum separating gel prepared in Tris-borate buffer ( $\mathrm{pH}$ 9.I). The electrophoretic separating time was usually I $\mathrm{mA}$ per tube for $5 \mathrm{~min}$ followed by $6 \mathrm{~mA}$ per tube for $55 \mathrm{~min}$ at $4^{\circ}$. Staining of the isozymes was achieved by incubation in the dark for $20-30 \mathrm{~min}$ with sodium $\beta$-naphthyl acid phosphate and Blue RR salt in $0.06 \mathrm{I} \mathrm{M} \mathrm{(pH} \mathrm{9.I)} \mathrm{borate} \mathrm{buffer} \mathrm{solution} \mathrm{con-}$ taining $0.00 \mathrm{I} \mathrm{M} \mathrm{MgCl}_{2}$. The acrylamide gels were then destained with the same solution used for the destaining of the starch gels.

Enzyme assay. Alkaline phosphatase activity was determined by a modification of the method of BEssey et al. ${ }^{33}$. Unless otherwise indicated, incubation mixtures contained the following components in a final volume of I.I $\mathrm{ml}: 50 \mu$ moles of glycine buffer ( $\mathrm{pH}$ I0.5), $0.5 \mu$ mole of $\mathrm{MgCl}_{2}, 7.5 \mu$ moles of sodium $p$-nitrophenyl phosphate, $0 . \mathrm{I} \mathrm{ml}$ of plasma or enzyme fraction containing $0 . \mathrm{I}$ to 0.5 units of enzyme in $5 \mu$ moles Tris- $\mathrm{HCl}$ buffer $(\mathrm{pH} 7.7)$. The reaction was stopped after $30 \mathrm{~min}$ at $37^{\circ}$ by the addition of $\mathrm{Io} \mathrm{ml}$ of $0.02 \mathrm{M} \mathrm{NaOH}$. The resulting absorbances were immediately read at 4 Io $\mathrm{nm}$.

A unit of alkaline phosphatase activity is defined as the amount of enzyme that releases I $\mu$ mole of $p$-nitrophenol per h from $p$-nitrophenyl phosphate. Specific activity is expressed in terms of $\mu$ moles of $p$-nitrophenol released per $h$ per $\mathrm{mg}$ of protein.

In the stoichiometric studies the alkaline phosphatase activity was also assayed by determination of inorganic phosphate released using a modification ${ }^{34}$ of the Fiske-SubbaRow ${ }^{35}$ procedure. 
RESULTS

Starch gel electrophoresis is the best means of demonstrating the differences in zymogram patterns obtained from individuals of different phenotypes. We have been able to confirm the observations of others that $\mathrm{B}$ and $\mathrm{O}$ individuals always give two isozymic bands, while in general individuals of group A non-secretors give one alkaline phosphatase isozyme and on occasion a second band is detectable. However, in confirmation of SHREFFLER's ${ }^{14}$ observations, there is a variability in the intensity of the second alkaline phosphatase isozyme.

This second isozyme band in plasma of group A non-secretors, not always detectable in starch gel zymograms, is invariably readily picked up by the acrylamide disc electrophoretic technique. The possibility of a contaminant in the starch gel selectively inhibiting one of the isozymes in the A non-secretor plasmas was tested for by the incorporation of boiled starch gel in the acrylamide prior to the run. No such inhibition was detected, although the migration of the isozymes in plasma of $A$ and $O$ individuals was greatly slowed in the acrylamide gels containing the starch.

The possibility that the different buffers, substrate, and staining procedures used in the starch and acrylamide gel techniques might have a selective effect on the second isozyme in plasma of A non-secretors was tested for and found not to influence the outcome. In all cases acrylamide gel disc electrophoresis gave two alkaline phosphatase isozymes in plasma of $\mathrm{A}, \mathrm{B}$, and $\mathrm{O}$ individuals, in contrast to starch gel electrophoresis which usually shows but one band in A non-secretors. Acrylamide disc electrophoresis was the procedure adopted for the routine work to be described because of its versatility, speed and sensitivity. In order to get clearcut sharp bands (Fig. 3) it is necessary to apply the plasma diluted (I:2) with buffer prior to the electrophoretic run. Use of concentrated plasma gave erratic and poor separations.

\section{Purification and separation of alkaline phosphatase isozymes}

All the fractionations were performed at $4^{\circ}$.

Ethanol fractionation. Outdated plasma from blood group $\mathrm{O}$ individuals was pooled (23I $8 \mathrm{ml})$ and chilled to $\mathrm{O}^{\circ}$. Ethanol $(95 \%)$ was previously chilled to $-\mathrm{IO}^{\circ}$ and slowly added to the plasma with constant stirring to a concentration of $55 \%$ ethanol $(2833 \mathrm{ml})$. The resulting precipitate was removed by centrifugation in a Sorvall centrifuge at $13200 \times g$. Further amounts of ethanol were added to the supernatant to an alcohol concentration of $65 \%$. This precipitate was dissolved in $230 \mathrm{ml}$ of $0.05 \mathrm{M}$ Tris- $\mathrm{HCl}$ buffer ( $\mathrm{pH} \mathrm{7.7)}$. Most of the alkaline phosphatase was found in this fraction $55^{-65 \%}$. Refractionation of the $55-65 \%$ fraction with ethanol resulted in a further purification (Table I). The final $55-65 \%$ ethanol precipitate was blue in color and contained the major portion of the ceruloplasmin and alkaline phosphatase activity of the initial plasma.

Sephadex $G$-20o treatment. This fraction, $\mathrm{I} 2 \mathrm{ml}$, was then applied to a Sephadex G-200 column $(2.2 \mathrm{~cm} \times 4 \mathrm{I} \mathrm{cm})$ previously equilibrated with the $0.05 \mathrm{M}$ Tris- $\mathrm{HCl}$ buffer $(\mathrm{pH} 7.7)$. The proteins were eluted with the same buffer at a flow rate of $\mathrm{I} \mathrm{ml}$ per $2 \mathrm{I} \mathrm{min}$ and $2-\mathrm{ml}$ fractions were collected for protein and enzyme assays. The elution pattern obtained is shown in Fig. I. The alkaline phosphatase activity eluted in Tubes $20-45$. However, only Tubes $23-39$ were pooled $(29 \mathrm{ml})$. 
TABLE I

PURIFICATION OF PLASMA ALKALINE PHOSPHATASE ISOZYMES

\begin{tabular}{|c|c|c|c|c|c|c|}
\hline Fraction & $\begin{array}{l}\text { Vol. } \\
(m l)\end{array}$ & $\begin{array}{l}\text { Protein } \\
(m g / m l)\end{array}$ & $\begin{array}{l}\text { Activity } \\
\text { (units(ml) }\end{array}$ & $\begin{array}{l}\text { Specific } \\
\text { activity }\end{array}$ & $\begin{array}{l}\text { Purification } \\
\text { factor }\end{array}$ & $\begin{array}{l}\% \text { of } \\
\text { total activity }\end{array}$ \\
\hline Original plasma & 2318 & 72.0 & I. 6 & 0.022 & I & 100 \\
\hline First ethanol $55-65 \%$ & 230 & 86.0 & 8.8 & 0.10 & $4 \cdot 5$ & $54 \cdot 5$ \\
\hline Second ethanol $55-65 \%$ & I2 & 80.0 & 78.0 & 0.97 & 44.0 & 25.2 \\
\hline Sephadex G-200 eluate & 29 & 6.0 & 13.2 & 2.2 & I OO.O & 10.3 \\
\hline DEAE-cellulose, minor, Pool I & 30 & 0.17 & 2.0 & $\mathrm{I} 2.0$ & 545.0 & I. .6 \\
\hline Peak I & 6.5 & 0.17 & $4 \cdot 14$ & $24 \cdot 3$ & $\operatorname{IIO}_{4} .0$ & 0.61 \\
\hline DEAE-cellulose, major, Pool II & 40.5 & 0.14 & 3.6 & 26,0 & I 182.0 & 4.0 \\
\hline Peak II & IO.O & 0.14 & $7 \cdot 4$ & 53.0 & 2409.0 & I. 9 \\
\hline
\end{tabular}

DEAE-cellulose chromatography. The solution obtained from the Sephadex G-200 eluate (Tubes 23-39) was passed through a DEAE-cellulose column (I.8 cm $\times$ $30 \mathrm{~cm}$ ) which had been previously washed and equilibrated with $0.05 \mathrm{M}$ Tris- $\mathrm{HCl}$ ( $\mathrm{pH} 7.7$ ) buffer. All the proteins were absorbed on the column. The column was then treated successively in a batchwise manner with $0.05 \mathrm{M}$ Tris- $\mathrm{HCl}, \mathrm{pH} 7.7$ ( $148 \mathrm{ml}$ ), followed by $\mathrm{NaCl}$ solutions of increasing molarity in the same buffer and in the following volumes: $0.02 \mathrm{M}(240 \mathrm{ml}), 0.04 \mathrm{M}(220 \mathrm{ml})$ and $0.06 \mathrm{M}(600 \mathrm{ml})$. Fractions of $5 \mathrm{ml}$ were collected, at the rate of $3 \mathrm{ml}$ in $5 \mathrm{~min}$, for protein and enzyme assays. The stepwise elution pattern obtained for the DEAE-cellulose column is shown in Fig. 2. There were two principal alkaline phosphatase peaks, the minor component eluting with the $0.04 \mathrm{M} \mathrm{NaCl}$ and major component with the $0.06 \mathrm{M} \mathrm{NaCl}$. The peak tubes of the minor, No. 128, and major, No. I73, were kept separate and referred to as the peak Tube I and peak Tube II, respectively. The minor component appears to be heterogeneous from its elution pattern. Only the contents of Tubes I26-I34

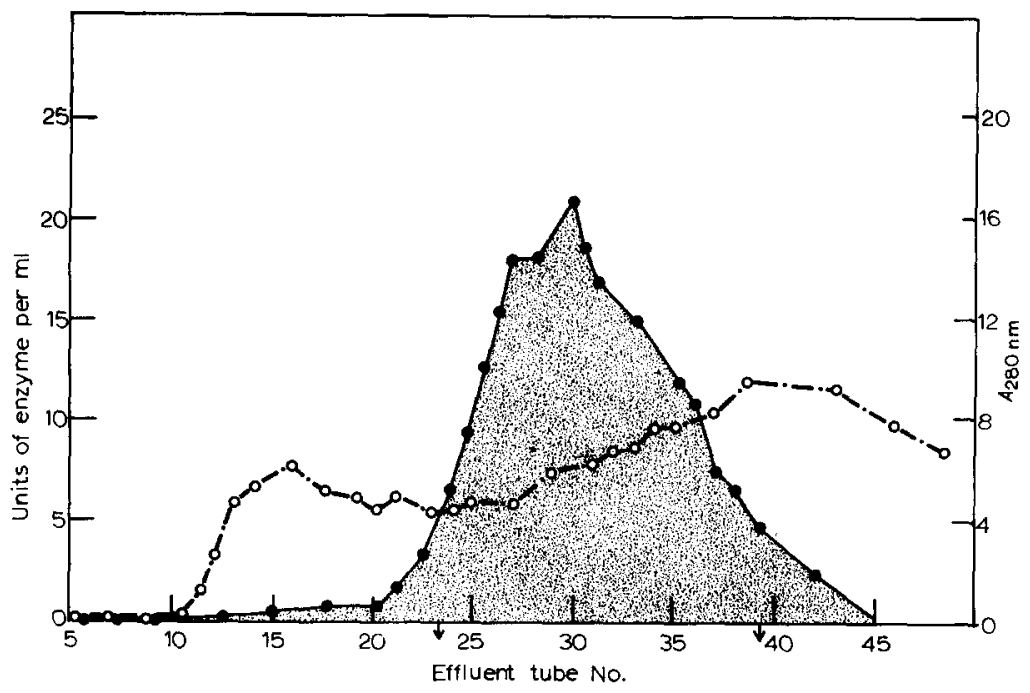

Fig. I. Elution pattern of 55-65\% ethanol refractionated material from Sephadex G-2oo. Protein concentration $\left(\mathrm{O}^{-}-\mathrm{O}^{-}\right.$) was determined by absorbance at $280 \mathrm{~nm}$ and the alkaline phosphatase activity (-) with p-nitrophenyl phosphate at $4 \mathrm{IO} \mathrm{nm}$.

Biochim. Biophys. Acta, 242 (197I) 108-122 


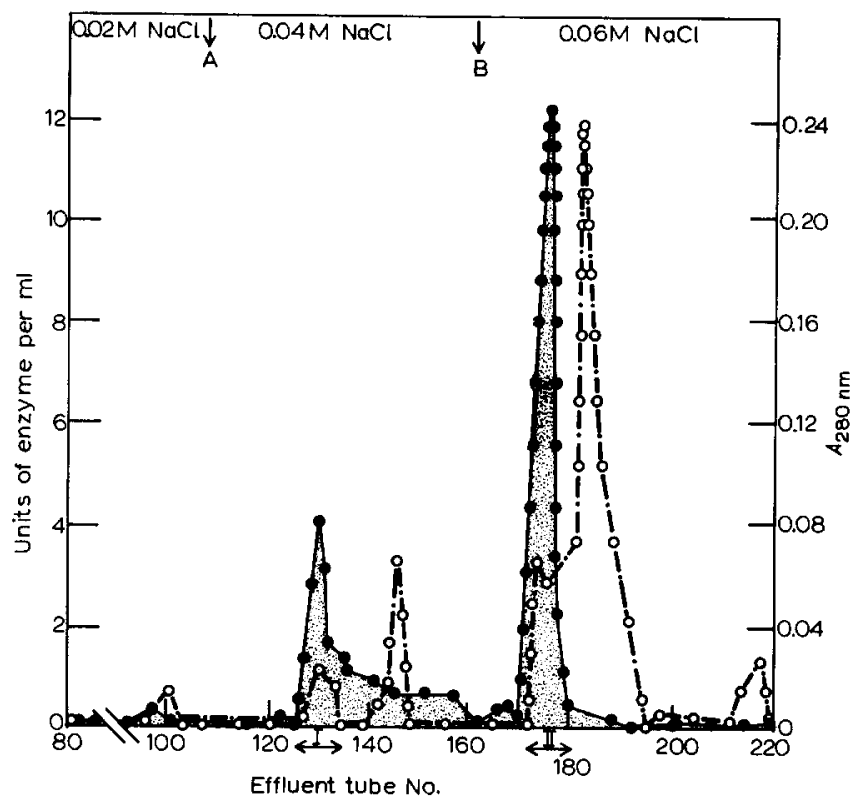

Fig. 2. DEAE-cellulose chromatography of Sephadex G-20o eluate. Protein concentration (O-.-O) and alkaline phosphatase activity (-O) were determined as in Fig. I. The arrows indicate where the salt concentration was changed (A) $0.04 \mathrm{M}$, (B) $0.06 \mathrm{M} \mathrm{NaCl}$ in $0.05 \mathrm{M}$ Tris- $\mathrm{HCl}$ $(\mathrm{pH} 7.7)$.

(with the exception of Tube I28) were pooled, and these constituted what is referred to as Pool I. Pool II represents the sharp major peak No. I7I-I77 (with the exclusion of Tube I73). A summary of the fractionation is shown in Table I.

\section{Purity of isozymes}

The course of fractionation at the various stages of purification (Table I) was followed by electrophoresis on polyacrylamide gels and stained for protein and alkaline phosphatase activity, as indicated in Methods. Fig. 3 shows the results obtained with the Sephadex G-200 eluate and the minor and major pools. Each individually gave but one band, the mixture of the two gave two bands identical to the initial Sephadex G-20o eluate.

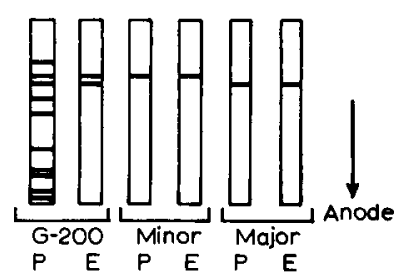

Fig. 3. Purity of alkaline phosphatase isozymes at various stages in the purification as monitored by polyacrylamide gel electrophoresis of 0.006 units of enzyme in Tris-borate buffer ( $\mathrm{pH} 9.0$ ) and stained for protein with Buffalo black $(\mathrm{P})$ and for alkaline phosphatase activity (E) by procedures described in Methods. 
TABLE II

COMPARISON OF ALKALINE PHOSPHATASE ISOZYMES ISOLATED FROM PLASMA OF DIFFERENT BLOOD PHENOTYPES

\begin{tabular}{|c|c|c|c|c|c|}
\hline $\begin{array}{l}\text { Blood } \\
\text { group }\end{array}$ & Fraction & $\begin{array}{l}\text { Activity } \\
\text { (units/ml) }\end{array}$ & $\begin{array}{l}\text { Protein } \\
(m g / m l)\end{array}$ & $\begin{array}{l}\text { Specific } \\
\text { activity }\end{array}$ & $\begin{array}{l}\% \text { of } \\
\text { total activity }\end{array}$ \\
\hline \multirow[t]{3}{*}{$\mathrm{O}$} & Original plasma* & 1.6 & 72.0 & 0.022 & - \\
\hline & Major peak & $7 \cdot 4$ & 0.14 & 53.0 & 2.00 \\
\hline & Minor peak & $4 \cdot I_{4}$ & 0.17 & $24 \cdot 3$ & 0.73 \\
\hline \multirow[t]{3}{*}{$\mathrm{O}$} & Original plasma* & I.O & 76.0 & 0.013 & - \\
\hline & Major peak & 3.6 & 0.092 & 39.2 & I.9 \\
\hline & Minor peak & I.O & 0.092 & I I.O & 0.56 \\
\hline \multirow[t]{3}{*}{0} & Original plasma ** & 2.4 & 62.0 & 0.039 & $\cdots$ \\
\hline & Major peak & 6.3 & O. I & 63.0 & $0.5^{8}$ \\
\hline & Minor peak & $4 \cdot 4$ & 0.2 & 22.0 & 0.32 \\
\hline \multirow[t]{3}{*}{ A } & Original plasma ** & $2, I$ & 62.0 & 0.034 & $\cdots$ \\
\hline & Major peak & 19.0 & 0.23 & 83.0 & І. 6 \\
\hline & Minor peak & $5 \cdot 5$ & I. I 2 & 5.0 & 0.5 \\
\hline \multirow[t]{3}{*}{ B } & Original plasma ** & 2.5 & 60.0 & .04 & - \\
\hline & Major peak & I 4.6 & 0.16 & 91.0 & I. I \\
\hline & Minor peak & 5.2 & 0.2 & 26.0 & 0.4 \\
\hline
\end{tabular}

Alkaline phosphatase material eluting with $0.04 \mathrm{M} \mathrm{NaCl}$ between Tubes $\mathrm{I} 34$ and I6o (Fig. 2) migrated with the speed of the minor component. Admixture of this with the peak tube of the minor component gave but one alkaline phosphatase band indicative of its relation to that isozyme.

Comparison of the alkaline phosphatase isozymes isolated from plasma $A, B$, and $O$ individuals

Table II summarizes the results of fractionation obtained with another batch of outdated O plasma and the plasmas of phenotype A, B, and $O$, respectively, from bloods after use for open heart surgery. It is interesting to note that despite the differences in specific activities of the major and minor peak tubes obtained from the different phenotypes in DEAE-cellulose fractionation, the ratio of the two specific activities is of the same order in material isolated from $B$ and $O$ individuals, approx. 3 , while it is much higher in the material isolated from blood of an A individual $(83 / 5$ or 16$)$. It would appear therefore that while the minor, electrophoretically slower migrating component is present also in the plasma of $\mathrm{A}$ individuals, it is actually present in smaller quantities as compared to that found in $\mathrm{B}$ and $\mathrm{O}$ individuals.

In each case the contents of the peak tubes of major and minor alkaline phosphatase were run separately and in admixture and compared to the original Sephadex G-20o eluates which contained the two isozymes. In all cases the double isozyme band pattern of the Sephadex G-2oo eluate was resolved into two separate components, major and minor, on the DEAE-cellulose column. These separated isozymes migrated as individual bands on disc electrophoresis. Remixing of the major 


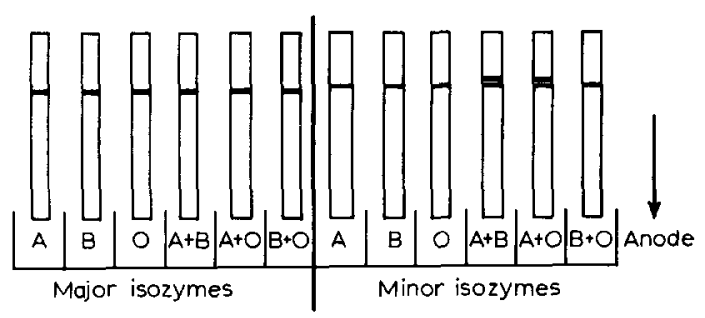

Fig. 4. Disc acrylamide gel electrophoresis of major and minor isozymes from $A, B$ and $O$ individuals alone and in admixture.

and minor gave rise to two bands again as in the initial Sephadex G-20o eluate. The isozymes isolated from a pool of $\mathrm{A}$ blood behaved in an analogous manner to the $\mathrm{B}$ and $\mathrm{O}$ systems (Fig. 3 ).

Next it was of interest to determine the electrophoretic pattern obtained from a mixture of the major components from $\mathrm{A}$ and $\mathrm{B}, \mathrm{A}$ and $\mathrm{O}$, and $\mathrm{B}$ and $\mathrm{O}$ run in parallel with the major components from $\mathrm{A}, \mathrm{B}$, and $\mathrm{O}$ run alone. Only one band was obtained in each case indicating the probable identity of the major alkaline phosphatase isozyme from the plasmas of A, B, and O phenotypes (Fig. 4).

On the other hand, admixture of the minor isozyme components gave an interesting distinction as shown in Fig. 4. Mixture of the minor" components of B
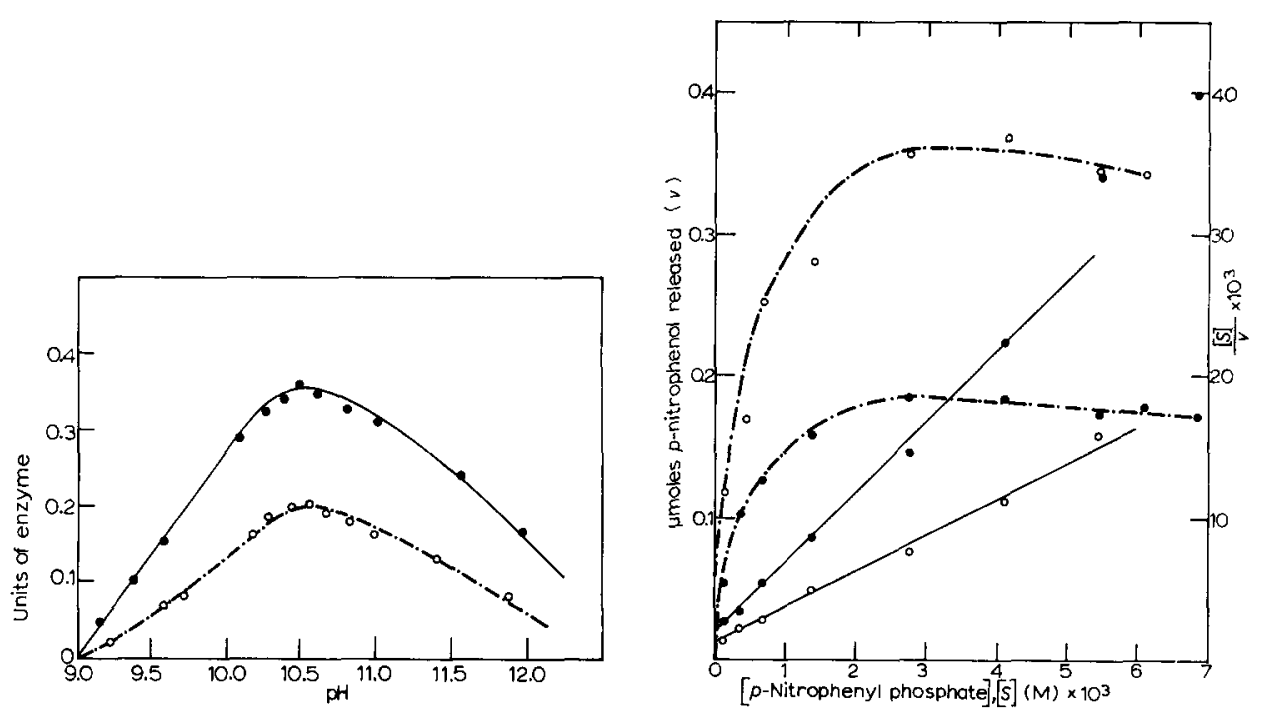

Fig. 5. Effect of $\mathrm{pH}$ on enzyme activity. Assays (30 min at $37^{\circ}$ ) were put up as follows: roo $\mu \mathrm{l}$ of the enzyme containing 0.36 unit of the major $(-)$ ) and 0.2 unit of the minor $\left(O_{-} \cdot-O^{-}\right), 500 \mu l$ of $0.1 \mathrm{M}$ glycine buffer of appropriate $\mathrm{pH}, 9 . \mathrm{I}-\mathrm{I} 2.3$, and $500 \mu \mathrm{l}$ of $p$-nitrophenyl phosphate, 7.5 $\mu$ moles.

Fig. 6. Effect of substrate concentration on reaction rate. Assays ( $3 \circ \mathrm{min}$ at $37^{\circ}$ ) were put up under the standard conditions with varying amounts of substrate and the minor $\left(\mathrm{O}^{-} \cdot-\mathrm{O}^{-}\right.$) or major (-) isozyme; the corresponding $[S] / v$ against $[S]$ plots for minor $(O-O)$ and major major (0) 
and $O$ gave one band as did each of the minor components from $A, B$, or $O$ run separately. However, mixtures of the minor components of $\mathrm{A}$ and $\mathrm{B}$ and of $\mathrm{A}$ and $\mathrm{O}$ in both cases gave rise to two bands, indicating their non-identity despite their very close mobility on the DEAE-cellulose column and disc electrophoresis.

\section{Kinetic studies}

The isozymes isolated from outdated group $\mathrm{O}$ plasma were used for these initial experiments. Maximal activity is obtained at $\mathrm{pH} 10.5$ for both isozymes (Fig. 5). The $K_{m}$ values, as determined by the HANES ${ }^{37}$ modification of the LineWEAVER-BURK ${ }^{36}$ plot, were approximately the same for the major, $0.4 \mathrm{mM}$ and minor, $0.35 \mathrm{mM}$, isozymes (Fig. 6). Under the conditions of enzyme assay used, the rate of hydrolysis of $p$-nitrophenyl phosphate is proportional to the amount of enzyme (Fig. 7) and period of incubation (Fig. 8).
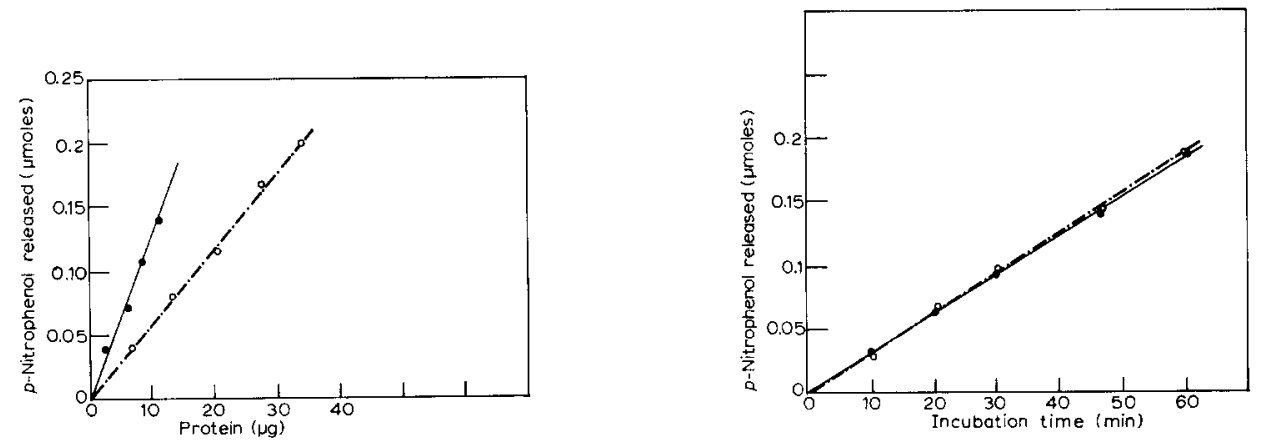

Fig. 7. Effect of enzyme concentration on reaction rate. Incubation mixtures were made up as described in the text. $O_{-}^{-}-\bigcirc$, minor;

Fig. 8. Effect of time on amount of $p$-nitrophenol released. Equivalent amounts of enzyme units were put up, minor $\left(\mathrm{O}^{-\cdot-O}\right)$ and major $(-0)$ components.

Stoichiometry. Typical incubation mixtures were put up with the two isozymes and both products-p-nitrophenol and inorganic phosphate-were determined.

With both isozymes equivalent amounts of the two products were released, indicating that the phosphate released is not utilized to phosphorylate either isozyme.

Inhibitors and activators. The effect of a number of compounds on the activities of the major and minor isozymes was investigated. The results obtained are shown in Table IIIa, and demonstrate that the activities of both isozymes are inhibited by EDTA and enhanced by $\mathrm{Mg}^{2+}$ and $\mathrm{Zn}^{2+}$. On the other hand $\mathrm{L}$-phenylalanine specifically inhibits the minor; while sodium taurocholate, deoxycholic acid and $\mathrm{K}_{3} \mathrm{PO}_{4}$ inhibit the major isozymes. The effect of $\mathrm{MgCl}_{2}$ concentration on the activity of both isozymes was found to be the same (Fig. 9).

There was a significant amount of activity, even in the absence of added $\mathrm{MgCl}_{2}$. In order to remove all metal ions, the enzymes were dialyzed against EDTA. The enzyme, Io $\mathrm{ml}$ of the DEAE eluate, was exhaustively dialyzed against four successive changes of $0.04 \mathrm{M}$ EDTA in the o.or M Tris- $\mathrm{HCl}(\mathrm{pH} 7.7)$ buffer in collodion bags. (The bags had previously been washed with acid and alkali as described in Materials and further washed with the $0.04 \mathrm{M}$ EDTA, in $0.05 \mathrm{M}$ Tris-HCl buffer prior to the 
TABLE III

EFFECT OF ADDITIVES ON THE ACTIVITIES OF MAJOR AND MINOR ISOZYMES FROM PLASMA OF GROUP O BLOOD

The experimental conditions were as follows: (a) undialyzed enzyme with no $\mathrm{MgCl}_{2}$ or $\mathrm{ZnCl}_{2}$ added, (b) dialyzed enzyme (EDTA-treated) and $\mathrm{ZnCl}_{2}$ added to a final concentration of $2 \mathrm{mM}$ in the incubation mixture, and (c) undialyzed enzyme, in the presence of $2 \mathrm{mM} \mathrm{ZnCl}_{2}$. The other components of the incubation mixture were as described under Enzyme assay.

\begin{tabular}{|c|c|c|c|c|c|c|c|c|c|}
\hline \multirow{4}{*}{$\begin{array}{l}\text { Additive } \\
(0.39 \mathrm{mM})\end{array}$} & \multicolumn{9}{|c|}{ Experimental conditions } \\
\hline & \multicolumn{3}{|l|}{$a$} & \multicolumn{3}{|l|}{$b$} & \multicolumn{3}{|l|}{$c$} \\
\hline & \multirow{2}{*}{$\begin{array}{l}\text { Major } \\
(\%)\end{array}$} & \multirow{2}{*}{$\begin{array}{l}\text { Minor } \\
(\%)\end{array}$} & \multirow{2}{*}{$\frac{\text { Major }}{\text { Minor }}$} & \multirow{2}{*}{$\begin{array}{l}\text { Major } \\
(\%)\end{array}$} & \multirow{2}{*}{$\begin{array}{l}\text { Minor } \\
(\%)\end{array}$} & \multirow{2}{*}{$\frac{\text { Major }}{\text { Minor }}$} & \multirow{2}{*}{$\begin{array}{l}\text { Major } \\
(\%)\end{array}$} & \multirow{2}{*}{$\begin{array}{l}\text { Minor } \\
(\%)\end{array}$} & Major \\
\hline & & & & & & & & & Minor \\
\hline None & IOO & IOO & 1.0 & 100 & 100 & 1.0 & 100 & IOO & I.O \\
\hline D-Tyrosine & 68 & $9 \mathrm{I}$ & 0.75 & 77 & 94 & 0.82 & 86 & IO3 & 0.83 \\
\hline L-Phenylalanine & 90 & 76 & I.I9 & 90 & 80 & I. 12 & $\mathrm{IO}_{4}$ & 85 & $\mathrm{I} .22$ \\
\hline Sodium arsenate & 79 & 87 & 0.91 & 63 & 83 & 0.76 & 68.5 & 95 & 0.73 \\
\hline Sodium taurocholate & 56 & 89 & 0.63 & 86 & 93 & 0.92 & 96.5 & $94 \cdot 5$ & 1.02 \\
\hline Sodium deoxycholate & 63 & 94 & 0.67 & 88 & 93 & 0.94 & 92 & 94 & 0.97 \\
\hline $\mathrm{K}_{3} \mathrm{PO}_{4}$ & 56 & 84 & 0.67 & 80 & 99 & $0.8 \mathrm{I}$ & IOI & 105 & 0.96 \\
\hline $\mathrm{KF}$ & 108 & I I 4 & 0.94 & 92 & 104 & 0.88 & I06 & 107 & I.O \\
\hline $\mathrm{CdCl}_{2}$ & 68 & $7^{8}$ & 0.87 & 80 & $7 \mathrm{I}$ & I. I 3 & 98 & 108 & $0.9 \mathrm{I}$ \\
\hline $\mathrm{Na}_{2} \mathrm{SO}_{4}$ & 86 & 94 & 0.91 & 100 & 102 & 0.98 & I I 6 & 103 & I. I 3 \\
\hline $\mathrm{K}_{2} \mathrm{SO}_{4}$ & 82 & 90 & $0.9 \mathrm{I}$ & I I I & IOI & I.IO & I I I & 104 & I.07 \\
\hline Bacitracin & 100 & I I 3 & 0.88 & 85 & 98 & 0.86 & 84.5 & 105 & 0.80 \\
\hline Oubain & 98 & 102 & 0.96 & 98 & IOO & 0.98 & 98 & 105 & 0.93 \\
\hline L-Tyrosine & 78 & 90 & 0.86 & 106 & IOI & I.05 & IOI & IIO & 0.92 \\
\hline D-Phenylalanine & 90 & 88 & 1.02 & 96 & 94 & 1.02 & 107 & 107 & 1.00 \\
\hline Citric acid & 63 & 77 & 0.82 & 98 & I & $0.9^{8}$ & 80 & $9 \mathrm{I} .5$ & 0.88 \\
\hline $\mathrm{ZnCl}_{2}$ & I 44 & I 43 & I.OO & & & & & & \\
\hline $\mathrm{MgCl}_{2}$ & I 31 & I 27 & I.03 & & & & & & \\
\hline $\mathrm{CoCl}_{2}$ & 67 & $6 \mathrm{I}$ & I.IO & 87 & 77 & I. I 3 & 87.5 & 102 & 0.86 \\
\hline $\mathrm{MnCl}_{2}$ & 49 & $5 \mathrm{I}$ & 0.96 & 80 & 71 & I. I 3 & 98 & 108 & $0.9 \mathrm{I}$ \\
\hline EDTA & 6 & 5 & I. 2 & 94 & 93 & I.o & 93.5 & 93 & I.O \\
\hline
\end{tabular}
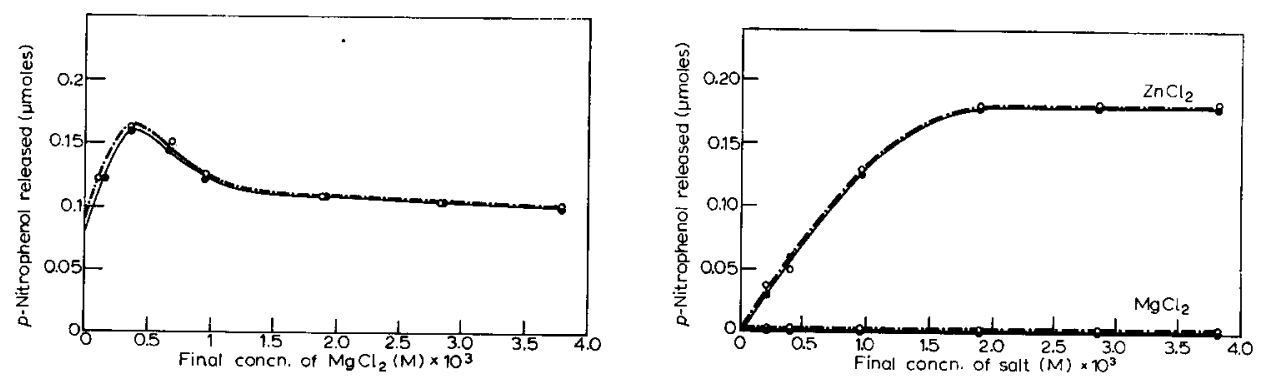

Fig. 9. Effect of $\mathrm{MgCl}_{2}$ on the rate of reaction. Equivalent amount of enzyme units were put up, minor $(\mathrm{O}-\cdot-\mathrm{O})$ and major $(-\mathrm{O})$ components.

Fig. Io. Effect of $\mathrm{MgCl}_{2}$ and $\mathrm{ZnCl}_{2}$ on the rate of reaction of EDTA-dialyzed alkaline phosphatase isozymes (O--O minor; - , major). 
addition of the enzyme.) After the dialysis against the EDTA, the bag contents were dialyzed exhaustively against four successive changes of Tris- $\mathrm{HCl}$ to remove the EDTA. The bag contents were then analyzed for protein content to determine if there was any change in concentration. No significant change in protein content was detected.

Neither the major nor minor dialyzed enzyme preparations showed any activity. Addition of $\mathrm{MgCl}_{2}$ or $\mathrm{CoCl}_{2}$ to the dialyzed enzymes resulted in no significant increase in activity, less than $6 \%$. Only the addition of $\mathrm{ZnCl}_{2}$ appeared to enhance the activity. Fig. Io shows the effect of $\mathrm{ZnCl}_{2}$ and $\mathrm{MgCl}_{2}$ on the major and minor enzymes (in equivalent amounts of units of enzymes) under substrate saturation conditions and in glycine buffer ( $\mathrm{pH}$ I0.5).

TABLE IV

SYNERGISTIC EFFECTS OF $\mathrm{Zn}^{2+} \mathrm{AND} \mathrm{Mg}^{2+}$

\begin{tabular}{|c|c|c|c|}
\hline \multirow[t]{2}{*}{ Nature of enzyme } & \multicolumn{2}{|c|}{ Additive } & \multirow{2}{*}{$\begin{array}{l}\text { Relative velocity } \\
\text { of reaction } \\
(\%)\end{array}$} \\
\hline & $\begin{array}{c}\mathrm{ZnCl} l_{2} \\
(\mu M)\end{array}$ & $\begin{array}{c}M g C l_{2} \\
(\mu M)\end{array}$ & \\
\hline \multirow[t]{4}{*}{ Undialyzed } & None & None & IOO \\
\hline & None & 0.5 & 212 \\
\hline & 0.5 & & 234 \\
\hline & 2.5 & & $23^{8}$ \\
\hline \multirow[t]{4}{*}{ Dialyzed } & 2.5 & 2.5 & 253 \\
\hline & 2.5 & & 233 \\
\hline & & 2.5 & 2.6 \\
\hline & 0.5 & 2.0 & 89 \\
\hline
\end{tabular}

In the absence of metal, presumably $\mathrm{Zn}^{2+}$, after EDTA dialysis, $\mathrm{Mg}^{2+}$ has little or no effect. It is only in the presence of minimal amounts of $\mathrm{Zn}^{2+}$ (Table IV) that $\mathrm{Mg}^{2+}$ shows the synergistic effects previously observed.

Effect of inhibitors and co-factors in presence and absence of $Z n^{2+}$. In view of the above observations it was of interest to determine the effects of the inhibitors and co-factors on the two isozymes under three distinct sets of conditions. The results obtained with isozymes from group $O$ are summarized in Table III, group $B$ in Table $\mathrm{V}$ and group $\mathrm{A}$ in Table VI.

The most significant observation is that in general the minor isozyme from group A plasma behaved like the major isozyme with the ratio of major to minor activities close to one. There was however one exception, with the additive $\mathrm{CdCl}_{2}$, where the ratio was I.3. Dialysis or addition of $\mathrm{ZnCl}_{2}$ to the dialyzed or undialyzed enzyme does not significantly change the ratio. On the other hand, the ratio of major/minor activities for $B$ and $O$ blood is similar and in general they are affected in the same manner under the different incubation conditions (Tables III, V, and VI).

\section{Alkaline phosphatase isozymes and blood group activity}

Blood group activity of Sephadex G-2oo eluates. Alkaline phosphatase has been reported to be a glycoprotein ${ }^{26}$. It is possible that the alkaline phosphatase isozyme would have the same type of oligosaccharide chains as are present in the blood group 
TABLE V

EFFECT OF ADDITIVES ON THE ACTIVITIES OF MAJOR AND MINOR ISOZYMES FROM PLASMA OF GROUP B BLOOD For experimental conditions, see Table III.

\begin{tabular}{|c|c|c|c|c|c|c|c|c|c|}
\hline \multirow{3}{*}{$\begin{array}{l}\text { Additive } \\
(0.39 \mathrm{mM})\end{array}$} & \multicolumn{9}{|c|}{ Experimental conditions } \\
\hline & \multicolumn{3}{|l|}{$a$} & \multicolumn{3}{|l|}{$b$} & \multicolumn{3}{|l|}{$c$} \\
\hline & $\begin{array}{l}\text { Major } \\
(\%)\end{array}$ & $\begin{array}{l}\text { Minor } \\
(\%)\end{array}$ & $\frac{\text { Major }}{\text { Minor }}$ & $\begin{array}{l}\text { Major } \\
(\%)\end{array}$ & $\begin{array}{l}\text { Major } \\
(\%)\end{array}$ & $\frac{\text { Minor }}{\text { Minor }}$ & $\begin{array}{l}\text { Major } \\
(\%)\end{array}$ & $\begin{array}{l}\text { Minor } \\
(\%)\end{array}$ & Major \\
\hline None & 100 & IOO & 1.0 & IOO & IOO & I.O & 100 & 100 & I.O \\
\hline D-Tyrosine & $67 \cdot 5$ & 99.5 & 0.68 & 80 & 90 & 0.88 & 88 & 97 & 0.91 \\
\hline L-Phenylalanine & 95.5 & 65 & I. 4 & 98 & 77 & I. 2 & 100 & 75 & $\mathrm{I} \cdot 3$ \\
\hline Sodium arsenate & 60 & 70.5 & 0.85 & 70 & 83 & 0.84 & 75 & 88 & 0.85 \\
\hline Sodium taurocholate & 58.5 & 75.5 & 0.77 & & & & & & \\
\hline Sodium deoxycholate & 74 & 93 & 0.79 & & & & & & \\
\hline $\mathrm{K}_{3} \mathrm{PO}_{4}$ & 73.5 & 85.5 & 0.86 & & & & & & \\
\hline KF & 90 & 107 & 0.84 & 99 & 108 & 0.92 & I 06 & $\mathrm{IO}_{4}$ & I.O \\
\hline $\mathrm{CdCl}_{2}$ & 54 & $5^{8}$ & 0.93 & 93 & 97 & $0.9 \mathrm{I}$ & 96 & IOI & 0.95 \\
\hline $\mathrm{Na}_{2} \mathrm{SO}_{4}$ & 85 & IOO & 0.85 & & & & & & \\
\hline $\mathrm{K}_{2} 5 \mathrm{O}_{4}$ & 83.5 & 96 & 0.86 & & & & & & \\
\hline Bacitracin & 95 & $\mathrm{II}_{4}$ & 0.84 & & & & & & \\
\hline Oubain & 96 & 105 & 0.92 & & & & & & \\
\hline
\end{tabular}

substances, and that these would have the characteristic terminal sugars specific to the given phenotype of the individual from whom the enzymes were isolated.

The Sephadex G-20o eluate represented a roo-fold purified alkaline phosphatase preparation and contained both isozymes. The Sephadex eluate preparations from plasmas of group $\mathrm{A}, \mathrm{B}$, and $\mathrm{O}$ were therefore tested for their $\mathrm{A}, \mathrm{B}$ and $\mathrm{H}$ activities

\section{TABLE VI}

EFFECT OF ADDITIVES ON THE ACTIVITIES OF MAJOR AND MINOR ISOZYMES FROM PLASMA OF GROUP A BLOOD

For experimental conditions, see Table III.

\begin{tabular}{|c|c|c|c|c|c|c|c|c|c|}
\hline \multirow{4}{*}{$\begin{array}{l}\text { Additive } \\
(0.39 \mathrm{mM})\end{array}$} & \multicolumn{9}{|c|}{ Experimental conditions } \\
\hline & \multicolumn{3}{|l|}{$a$} & \multicolumn{3}{|l|}{$b$} & \multicolumn{3}{|l|}{$c$} \\
\hline & \multirow{2}{*}{$\begin{array}{l}\text { Major } \\
(\%)\end{array}$} & \multirow{2}{*}{$\begin{array}{l}\text { Minor } \\
(\%)\end{array}$} & \multirow{2}{*}{ Major } & \multirow{2}{*}{$\begin{array}{l}\text { Major } \\
(\%)\end{array}$} & \multirow{2}{*}{$\begin{array}{l}\text { Minor } \\
(\%)\end{array}$} & \multirow{2}{*}{$\frac{\text { Major }}{\text { Minor }}$} & \multirow{2}{*}{$\begin{array}{l}\text { Major } \\
(\%)\end{array}$} & \multirow{2}{*}{$\begin{array}{l}\text { Minor } \\
(\%)\end{array}$} & \multirow{2}{*}{ Major } \\
\hline & & & & & & & & & \\
\hline None & Ioo & IOO & I.O & 100 & I OO & I.O & 100 & IOO & I.O \\
\hline D-Tyrosine & 100 & IOO & 1.0 & 97 & 100 & 0.97 & I06 & 105 & I.O \\
\hline L-Phenylalanine & Ioo & 100 & 1.0 & IOO & IOI & I.O & 103 & 100 & t.o \\
\hline Sodium arsenate & $7^{6}$ & 84 & 0.90 & 88 & 92 & 0.95 & 90 & 94 & 0.96 \\
\hline Sodium taurocholate & 75 & 75 & 0.97 & & & & & & \\
\hline Sodium deoxycholate & $8 \mathrm{I}$ & 86 & 0.94 & & & & & & \\
\hline $\mathrm{K}_{3} \mathrm{PO}_{4}$ & 107 & 107 & I.O & & & & & & \\
\hline $\mathrm{KF}$ & I02 & I06 & 0.96 & I I I & I IO & I.O & 118 & I $\mathbf{I} 8$ & I.O \\
\hline $\mathrm{CdCl}_{2}$ & $37 \cdot 5$ & 29 & I. 3 & & & & & & \\
\hline $\mathrm{Na}_{2} \mathrm{SO}_{4}$ & 88 & 98 & 0.90 & & & & & & \\
\hline $\mathrm{K}_{2} \mathrm{SO}_{4}$ & 100 & IOO & I.O & & & & & & \\
\hline Bacitracin & 95 & 84 & I. I & & & & & & \\
\hline Oubain & 105 & I I I & 0.94 & & & & & & \\
\hline
\end{tabular}


by the inhibitions of hemagglutination technique ${ }^{38}$ using human $\mathrm{A}, \mathrm{B}$, and $\mathrm{P}$ cells and human anti-A and anti-B and eel anti-H sera.

No $\mathrm{A}, \mathrm{B}$, or $\mathrm{H}$ blood group activity was detected in any of the preparations tested. Addition of the appropriate blood group substance to the Sephadex G-200 eluate was readily detected by the inhibition of hemagglutination technique.

Effect of blood group substances on the electrophoretic mobility of the alkaline phosphatase isozymes. It has been postulated ${ }^{\mathbf{1 1}}$ that the major, faster migrating isozyme of alkaline phosphatase might form a complex with some blood group active glycoprotein. This would result in a high molecular weight complex with a diminished mobility that might correspond to that of the minor component. To test for this possibility, an electrophoretic run was put up in acrylamide gel with the major alkaline phosphatase isozymes run alone and in admixture with different. blood group substances ((a) purified hog submaxillary glycoprotein with A or $\mathrm{H}$ specificity ${ }^{39}$, (b) partially purified hog gastric mucin containing both $\mathrm{A}$ and $\mathrm{H}$ active glycoproteins $^{\mathbf{4 0}}$, and (c) rhesus monkey gastric lining containing B substance). The major alkaline phosphatase isozyme gave but one band corresponding to the major band in mobility whether run alone or in admixture with any of the blood group substances cited, thus indicating that at least at the $\mathrm{pH}$ at which the electrophoresis was carried out, there is no complexing of the major alkaline phosphatase with blood group active glycoprotein to give a slower migrating isozyme equivalent to the minor isozymic band.

\section{DISCUSSION}

By a number of simple steps it has been possible to separate and purify the two isozymes of alkaline phosphatase from group $O$ plasma. The major and minor isozymes (the faster and slower electrophoretically migrating bands, respectively) have been obtained in a high state of purity, 2400- and I Ioo-fold, respectively. Nonetheless, they are still not homogeneous proteins since the specific activities of the enzymes in the peak tube were at least twice as high as the pool corresponding to that isozyme eluted from the DEAE-cellulose column.

Remixing the major and minor isozymes which had been separated on DEAEcellulose gave back the two original isozymic bands found in the Sephadex eluate and original plasma. Therefore, despite the low overall yield of the purified enzymes, they represent the two isozymes initially present in group $O$ plasma.

Kinetic studies of the two isozymes indicate their close similarities with respect to (a) $\mathrm{pH}$ optimum, I0.5, (b) $K_{m}, 0.40$ and $0.35 \mathrm{mM}$, and (c) behavior towards EDTA, $\mathrm{Mg}^{2+}$ and $\mathrm{Zn}^{2+}$.

The two isozymes, however, differ in their (a) electrophoretic mobility, (b) adsorbability on DEAE-cellulose and (c) their reactivity towards $p$-nitrophenyl phosphate in the presence of a number of different compounds. Some of these, e.g. Dtyrosine, sodium taurocholate, sodium deoxycholate and $\mathrm{K}_{3} \mathrm{PO}_{4}$, preferentially inhibit the major as compared to the minor enzyme. On the other hand the reverse is true with other compounds, $c . g$. L-phenylalanine which preferentially inhibits the minor isozyme.

The effect of these substances is more readily detectable in the absence of zinc and in general they are abolished on addition of zinc ions, with one notable exception, 
L-phenylalanine. The addition of $\mathrm{Zn}^{2+}$ moreover also abolishes the differences between the reactivities of the major and minor isozymes.

It is interesting to note that neither isozyme is inhibited by $\mathrm{F}^{-}$or preferentially modified by $\mathrm{Na}^{+}$or $\mathrm{K}^{+}$, oubain or bacitracin.

In contrast to starch electrophoresis, disc electrophoresis on acrylamide gels persistently showed two isozymic bands in all blood groups, $\mathrm{A}$ as well as B and $\mathrm{O}$. We are grateful to Dr. D. Shreffler for undertaking to run a number of plasmas from individuals of different blood types on starch gel electrophoresis at the same time as we ran them on disc electrophoresis. Using starch gel electrophoresis it was possible to differentiate between the zymograms obtained from plasmas of A non-secretors ( $\mathrm{I}$ band) as compared to $\mathrm{B}$ and $\mathrm{O}$ ( 2 bands). Disc electrophoresis could not distinguish between them, as two bands were also obtained in the A non-secretors. We believe this difference in behavior with the two techniques is due to the greater sensitivity and concentrating capability of the disc acrylamide electrophoretic procedure.

Fractionation of pooled plasmas from a number of individuals of known phenotype: groups $\mathrm{A}, \mathrm{B}$, and $\mathrm{O}$ by procedures outlined in this communication gave rise to two isozymes in each case, thus confirming the observations with the disc electrophoresis. However, the ratio of specific activities of the major and minor isozymes isolated from $B$ and $O$ plasmas were of the same order of magnitude, 3 , and much less than that isolated from A plasma where it was approximately I6 (Table II).

Disc electrophoretic analysis of the major and minor isozymes isolated from plasmas of group $\mathrm{A}, \mathrm{B}$ and $\mathrm{O}$ indicated that in all probability the major component is the same in all three phenotypes. However, the minor component from A is slightly slower migrating than that isolated from $\mathrm{B}$ and $\mathrm{O}$, which have the same mobility.

These observations differentiate the minor isozyme from $\mathrm{A}$ as compared to that from $\mathrm{B}$ and $\mathrm{O}$ plasmas. This distinction is further substantiated by the effect of various substances on the reactivity of the major and minor isozymes. The minor component of $A$ behaves more like the major of $A$. In contrast, greater differences in reactivity are observed between the major and minor components of $B$ and $O$. The most interesting of these compounds is L-phenylalanine which has no effect on the major and minor isozymes of group A blood. In contrast it specifically inhibits the minor isozyme in $\mathrm{B}$ and $\mathrm{O}$.

It would appear that, in confirmation of previous workers, there is a difference in the isozymes from group A plasma as compared to that of $\mathrm{B}$ and $\mathrm{O}$. This difference, however, is not due to blood group-like oligosaccharides present in the alkaline phosphatase isozyme molecules, nor is it due to a complex formation between the isozymes and glycoproteins with blood group activity.

\section{ACKNOWLEDGMENTS}

This work was supported by a National Science Foundation Grant No. 93 from the Horace H. Rackham School of Graduate Studies, the University of Michigan.

\section{REFERENCES}

I S. H. Boyer, Science, 134 (I96I) IOO2.

2 A. W. Hodson, A. L. Latner and L. Raine, Clin. Chim. Acta, 7 (I962) 255. 
3 V. R. Cunningham and J. G. Rimer, Biochem. J., 89 (I963) 508.

4 N. R. Keiding, Scand. J. Clin. Lab. Invest., I I (I959) Io6.

5 I. N. RosenberG, J. Clin. Invest., 38 (1959) 630.

6 M. Schlamowitz and O. Bodansky, J. Biol. Chem., 234 (I959) I 433.

7 K. E. Arfors, L. Beckman and L. G. Lundin, Acta Genet. Basel, i 3 (I963) 89.

8 K. E. Arfors, L. Beckman and L. G. Lundin, Acta Genet. Basel, I 3 (1963) 366.

9 B. GAHNE, Nature, I99 (1963) 305.

io J. Rendel and C. Stormont, Proc. Soc. Exptl. Biol. Med., I I5 (1964) 853.

I I L. Beckman, Acta Genet. Basel, I 4 (1964) 286.

I 2 L. Beckman, G. Björling and A. Heiken, Acta Genet. Basel, I6 (I966) 305.

I J. C. Robinson and L. A. Goldsmith, Vox Sanguinis, i 3 (1967) 289.

I 4 D. C. ShrefFler, Am. J. Human Genet., I 7 (I965) $7 \mathbf{I}$.

is M. J. S. Langman, E. Leuthold, E. B. Robson, J. Harris, J. E. Luffman and H. Harris, Nature, 2 I 2 (I966) $4 \mathrm{I}$.

16 W. H. Fishman, S. Green and N. I. Inglis, Nature, 198 (I963) 685.

I 7 W. H. Fishman, N. I. Inglis and M. J. Krant, Clin. Chim. Acta, i 2 (1965) 298.

is N. K. Ghosh and W. H. Fishman, J. Biol. Chem., 24 I (I966) 25 I6.

ig J. H. Kreisher, V. A. Ciose and W. H. Fishman, Clin. Chim. Acta, i i (1965) 122.

20 A. Garen and C. Levinthal, Biochim. Biophys. Acta, 38 (1960) 470.

2 I M. H. Malamy and B. I. Horecker, Biochemistry, 3 (I964) I 893.

22 R. K. Morton, Biochem. J., 57 (1954) 595.

23 J. C. Mathies, J. Biol. Chem., 233 (1958) I I 2 I.

24 j. Engström, Biochim. Biophys. Acta, 52 (I96I) 36.

25 L. Engström, Biochim. Biophys. Acta, 92 (1964) 7 I.

26 N. K. Ghosh, Ann. N.Y. Acad. Sci., I66 (I969) 604.

27 O. Aalund, J. Rendel and R. A. Freedland, Biochim. Biophys. Acta, i do (ig65) II 3.

28 O. Warburg and W. Christian, Biochem. Z., 3Io (I94I) 384 .

29 O. H. Lowry, N. J. Rosebrough, A. L. Fark and R. J. Randall, J. Biol. Chem., I93 (I 95 I) 265.

30 O. Sмrthies, Biochem. J, 6I (I955) 629.

31 S. H. Lawrence, P. J. Melnick and H. E. Weimer, Proc. Soc. Exptl. Biol. Med., Io5 (I960) 572 .

32 B. J. Davis, Ann. N.Y. Acad. Sci., I2I (I964) 404.

33 O. A. Bessey, O. H. Lowry and M. J. Bruck, J. Biol. Chem. I64 (1946) 32 I.

34 R. B. Hulbert, H. H. Schmitz, A. F. Brumm and R. Van Potter, J. Biol. Chem., 209 (I954) 23.

35 C. H. Fiske and Y. SubbaRow, J. Biol. Chem., 66 (1925) 375.

$36 \mathrm{H}$. Lineweaver and D. Burk, $\mathrm{J}$. Am. Chem. Soc., 56 (I934) 658.

37 C. S. Hanes, Biochem. J., 26 (1932) I 406.

38 D. Aminoff, W. T. J. Morgan and W. M. Watkins, Biochem. J., 46 (1950) 426.

39 D. Aminoff, M. P. Morrow and C. J. D. Zarafonetis, Federation Proc., 23 (1964) 274. 4o W. T. J. Morgan and H. K. King, Biochem. J., 37 (1943) 640.

Biochim. Biophys. Acta, 242 (I971) 108-1 22 